\title{
PENDUGAAN STOK IKAN DI SUNGAI KAPUAS, KALIMANTAN BARAT
}

\author{
Agus Djoko Utomo dan Susilo Adjie \\ Peneliti pada Balai Riset Perikanan Perairan Umum, Mariana-Palembang \\ Teregistrasi I tanggal: 29 Agustus 2008; Diterima setelah perbaikan tanggal: 17 Nopember 2008; \\ Disetujui terbit tanggal: 27 Nopember 2008
}

\begin{abstract}
ABSTRAK
Sungai Kapuas, Kalimantan Barat mempunyai tipe ekosistem yang kompleks dan keanekaragaman jenis ikan tinggi. Sungai Kapuas ini sudah mendapat tekanan dari luar terutama dari pertanian, perkebunan, dan pertambangan. Akibatnya, beberapa jenis ikannya sudah mulai langka antara lain ringo (Datniodes quadrifsciatus), siluk (Scleropags formosus), belantau (Macrochirichthys macrochirus), dan kapas (Rohteichthys microlepis). Suatu kajian stok ikan dengan menggunakan metode akustik dilakukan pada bulan Juli dan Desember 2006 di Sungai Kapuas. Lokasi yang diambil adalah ruas Sungai Kapuas dari Pontianak ke hilir sampai Muara Jungkat, ruas Sungai Kapuas dan ruas anak sungainya sekitar Tayan, ruas anak sungai perairan banjiran di kawasan Sentarum dan satu buah danau sungai mati yaitu Danau Empangau. Untuk mengetahui komposisi jenis ikan, pengambilan contoh ikan dilakukan dan hasil tangkapan dicatat oleh enumerator. Stok ikan di hilir antara Pontianak dan Muara Jungkat adalah $1.847 \mathrm{ind}$./Ha, di Tayan pada sungai Kapuas dan anak sungainya masing-masing adalah 157 dan 403 ind./Ha, di kawasan Sentarum berkisar 1.087 - 1.634 ind./Ha, dan di Danau Empangau adalah 5.708 ind./Ha. Jenis ikan yang mendominansi di perairan antara Pontianak ke Muara Jungkat yaitu sengarat (Kryptopterus trichopterus) dan baung (Mystus nemurus), di Tayan yaitu kotol mulut (Amblyrhycnchichthys truncatus) dan kelabau (Osteochilus melanopleura), di kawasan Sentarum yaitu bauk (Labiobabrus spp.), sepat (Trichogaster trichopterus), dan toman (Channa micropeltes), serta di Danau Empangau yaitu entukan (Thynnichthys thynnoides), umpan (Puntius waandersii), dan biawan (Helostoma temminckii).
\end{abstract}

KATAKUNCl: $\quad$ stok ikan, Sungai Kapuas, Kalimantan Barat

ABSTRACT: $\quad$ Fish stock assessment in Kapuas River, West Kalimantan. By: Agus Djoko Utomo and Susilo Adjie

Kapuas River, West Kalimantan has various ecosystem types and high fish biodiversity. This river has been pressured by other sectors such as agriculture, plantation, and mining. Some of fish species such as ringo (Datniodes quadrifsciatus), siluk (Scleropags formosus), belantau (Macrochirichthys macrochirus), and kapas (Rohteichthys microlepis) endanger. A study on fish stock assessment using accoustic methods was done on July and December 2006 in Kapuas River. The locations selected in this study were down stream from Pontianak to Muara Jungkat, segment of Kapuas River and its tributary around Tayan area, in segment of Sentarum floodplains (Empangau oxbow lake). Average fish stock in downstream segment was 1,847 ind./Ha, around Tayan in main river and its tributary was 157 ind./Ha and 403, respectively, in Sentarum ranged 1,087 - 1,634 ind./Ha and in Empangau Lake was 5,708 ind./Ha. Fish species dominance from Pontianak to Muara Jungkat was sengarat (Kryptopterus sp.) and baung (Mystus nemurus), in Tayan was kotol mulut (Amblyrhycnchichthys truncatus) and kelabau (Osteochilus melanopleura), in Sentarum was bauk (Labiobabrus spp.), sepat (Trichogaster trichopterus), and toman (Channa micropeltes), and in Empangau Lake were entukan (Thinnichthys thynnoides), umpan (Puntius waandersii), and biawan (Helostoma temminckii).

\section{KEYWORDS: $\quad$ fish stock, Kapuas River, West Kalimantan}

\section{PENDAHULUAN}

Luas perairan umum di Propinsi Kalimantan Barat adalah sekitar dua juta $\mathrm{Ha}$, terdiri atas danau, rawa, dan sungai. Sungai Kapuas merupakan sungai terbesar di Kalimantan Barat dan terpanjang di Indonesia yaitu $1.080 \mathrm{~km}$ (Sutikno, 1981). Sepanjang aliran Sungai Kapuas mempunyai tipe ekologi yang sangat kompleks, namun secara garis besar ada tiga tipe yang penting yaitu 1) perairan di hulu sungai (upstream) (>45 $\mathrm{m}$ di atas permukaan laut, dpl.) yang berarus deras sampai sedang, pada umumnya berbatu, sekeliling sungai merupakan daerah perkebunan atau perladangan - tipe ini terdapat di 
sebelah hulu daerah Bunut Kabupaten Kapuas Hulu; 2) sungai bagian tengah (middle stream) (5 - $45 \mathrm{~m}$ dpl.), banyak terdapat rawa banjiran, berarus tenang, banyak terdapat anak sungai, sekeliling sungai merupakan hutan rawang - tipe perairan ini banyak ditemui antara Sanggau dan Bunut, khusus untuk tipe rawa banjiran, banyak terdapat di kawasan Sentarum Kabupaten Kapuas Hulu, dan 3) perairan yang dipengaruhi oleh pasang surut air laut, terdapat di bagian hilir sungai (down stream) (0 - $15 \mathrm{~m} \mathrm{dpl}$.) tipe ini ditemui mulai dari muara sungai sampai Sanggau (60 km dari Pontianak) (Utomo et al., 1991).

Sungai Kapuas memiliki keanekaragaman hayati yang tinggi, terutama jenis ikannya yang lebih dari 200 spesies (Dudley, 1996). Di antara jenis-jenis ikan tersebut banyak terdapat ikan bernilai ekonomis seperti ikan pipih (Notopterus chitala), betutu (Oxyeleotris marmorata), jelawat (Leptobarbus hoeveni), semah (Tor spp.), dan siluk (Scleropages formosus). Aktivitas penangkapan di Sungai Kapuas banyak terdapat di Sungai Kapuas bagian tengah. Daerah Sungai Kapuas ini mencakup kawasan konservasi yang dikelola oleh PHPA yaitu Danau Sentarum yang luasnya sekitar $80.000 \mathrm{Ha}$ yang banyak terdapat hutan rawa (Giesen, 1995). Hutan rawa di Sungai Kapuas mempunyai peran penting bagi kelestarian sumber daya ikan, yaitu sebagai daerah pemijahan, tempat berlindung, dan tempat mencari makanan bagi berbagai jenis ikan (Utomo \& Asyari, 1999).

Pollnac \& Malvestuto (991) mengatakan, Sungai Kapuas, Kalimantan Barat mulai tampak dipengaruhi oleh tekanan ekologis dari sektor pertanian dan industri. Sudah menjadi isu nasional bahwa potensi sumber daya ikan di perairan umum daratan cenderung menurun, bahkan beberapa jenis ikan menjadi langka antara lain ringo (Datniodes quadrifaciatus), siluk (Sclerophages formosus), belantau (Macrochirichthys macrochirus), dan kapas (Rohteicthys microlepis).

Penelitian ini bertujuan untuk mengetahui stok ikan di berbagai tipe ekosistem perairan yang terdapat di sepanjang aliran Sungai Kapuas, Kalimantan Barat, sehingga dapat diketahui tipe ekosistem yang mempunyai stok ikan banyak dan sebaliknya, tipe ekosistem yang mempunyai stok ikan tinggal sedikit. Informasi ini diharapkan dapat menjadi bahan masukkan bagi pengambil kebijakan pengelolaan sumber daya ikan di daerah aliran Sungai Kapuas.

\section{BAHAN DAN METODE}

Penelitian ini dilakukan pada bulan Juli dan Desember 2006. Lokasi penelitian pendugaan stok dilakukan di empat lokasi berbeda yaitu dari Pontianak sampai Muara Sungai Jungkat, Tayan (meliputi Sungai Kapuas dan Sungai Tayan), Semitau (meliputi Sungai Kapuas, dan Sungai Tawang), dan Danau Empangau.

Pendugaan stok ikan menggunakan alat akustik SIMRAD EY-60 portable scientific echosounder yang dilengkapi dengan sebuah transducer $120 \mathrm{khz}$. Alat ini dipasang pada sisi kanan kapal dengan kekuatan mesin 8 GT (Tabel 1). Desain alur pengambilan data di perairan dengan cara transek zig-zag. Data yang diperoleh dari alat akustik berupa data gram, kemudian diolah dengan menggunakan perangkat lunak ER-60 menjadi data threshold. Pengolahan data lebih lanjut untuk mendapatkan informasi mengenai densitas ikan dilakukan dengan menggunakan perangkat lunak SONAR-4 (post processing data). Selanjutnya, data disimpan dalam bentuk file ASCII, kemudian ditabulasi dengan menggunakan perangkat lunak microsoft exel. Data yang ditampilkan oleh alat akustik tersebut adalah stok ikan dalam individu per Hektar, kedalaman, posisi geografi, dan jarak tempuh.

Untuk informasi selanjutnya, terutama tentang komposisi jenis ikan dalam stok tersebut, maka dilakukan pengambilan contoh ikan dari hasil tangkapan nelayan dan pencatatan data hasil tangkapan dari enumerator. Contoh ikan selama penelitian diambil dengan cara memilih alat tangkap yang tidak selektif yaitu hampang (barrier traps) dan jermal (fyke net). Enumerator yang dipakai dalam penelitian ini adalah nelayan tetap yang menggunakan alat tangkap yang tidak selektif. Jumlah enumerator yang dipakai adalah dua orang per lokasi. Komposisi hasil tangkapan dari pengambilan contoh ikan maupun dari enumerator dianggap mewakili komposisi stok ikan yang tercatat oleh alat akustik.

\section{HASIL DAN BAHASAN}

\section{Pendugaan Stok Ikan Sekitar Pontianak sampai Muara Jungkat}

Lokasi pendugaan stok ikan di bagian hilir sungai mulai dari kota Pontianak sampai Muara Jungkat berjarak sekitar $42,8 \mathrm{~km}$, mempunyai kisaran kedalaman air maksimal 6 - 15 m (Lampiran 1, Gambar 1). Hasil pendugaan stok menunjukkan bahwa Sungai Kapuas bagian hilir (Pontianak sampai Muara 
Tabel 1. Peralatan akustik untuk pendugaan stok ikan Table 1. Accustic equipment for estimating fish stock

\begin{tabular}{cll}
\hline No. & \multicolumn{1}{c}{ Jenis alat/Equipment tools } & \multicolumn{1}{c}{ Kegunaan/Utilizations } \\
\hline 1. & Akustik portable scientific echosounder SIMRAD & Alat utama penduga stok ikan. \\
& EY-60, transducer $120 \mathrm{khz}$ & \\
2. & Satu unit portable gienset, 1.000 watt & Pembangkit listrik selama dalam perjalanan pendugaan stok. \\
3. Kapal dari kayu, mesin berkekuatan $8 \mathrm{GT}$ & $\begin{array}{l}\text { Pengangkut peralatan, tempat memasang alat akustik di } \\
\text { samping badan kapal. }\end{array}$ \\
4. & Laptop, memory $>2 \mathrm{~GB}$, hardisk $>80 \mathrm{~GB}$ & Akuisisi data, selama alat akustik beroperasi di dalam kapal. \\
\hline
\end{tabular}

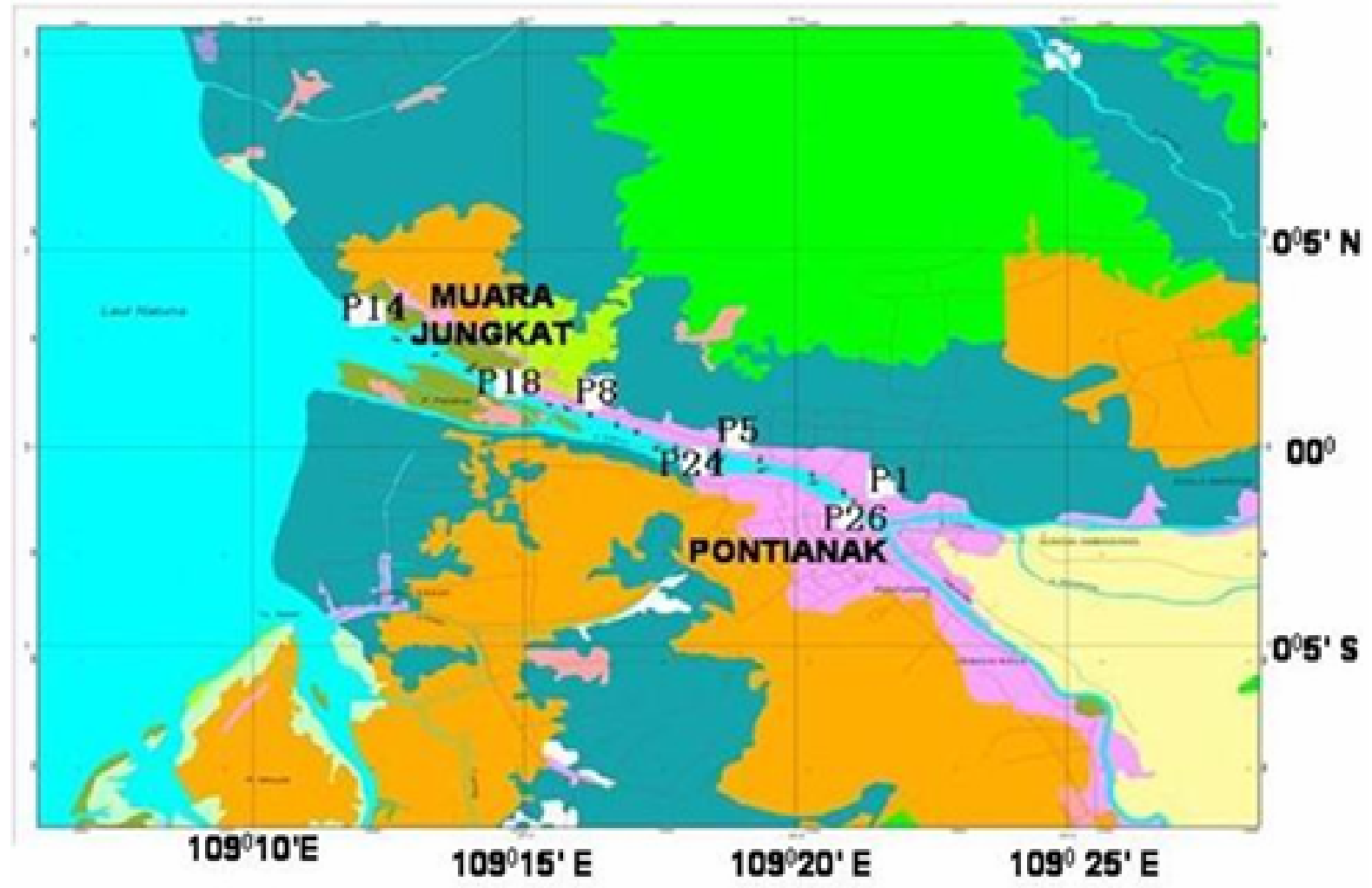

Gambar 1. Peta pendugaan stok ikan dari Pontianak sampai dengan Muara Jungkat. Figure 1. Map of fish stock assessment from Pontianak until Muara Jungkat.

Jungkat) mempunyai densitas stok paling tinggi (1.846 ind./Ha), dibanding bagian lainnya. Hal ini mungkin disebabkan karena perairan di daerah hilir sungai pada umumnya mempunyai kesuburan tinggi. Nutrien dari bagian hulu sungai akhirnya terbawa arus ke hilir yang akan dimanfaatkan oleh fitoplankton, selanjutnya dimanfaatkan oleh ikan (Barnes \& Green, 1971).

Berdasarkan pada catatan enumerator dan hasil pengambilan contoh, komposisi jenis ikan yang mendominansi perairan di sekitar Pontianak sampai Muara Jungkat adalah ikan sengarat (Kryptopterus sp.), baung, (Mystus nemurus), belida atau pipih (Notopterus chitala), tebengalan (Puntius bulu), dan tapa (Wallago spp.). Jenis Ikan yang dominan tersebut sering tertangkap di perairan campuran antara rawa pasang surut dengan rawa banjiran, seperti di daerah Terentang dekat Pontianak. Sebagian besar ikan dominan tersebut merupakan ikan karnivora yang ukurannya relatif besar seperti ikan sengarat (Cryptopterus sp.), tapa (Wallago spp.), dan belida (Notopterus chitala). Perairan yang banyak terdapat ikan karnivora dan ukuran relatif besar merupakan indikator bahwa perairan tersebut banyak terdapat ikan. Ikan campuran menempati $6 \%$ yang terdiri atas janggut (Polynemus dubius), sembilang (Plotosus canius), duri (Arius venosus), dukang (Arius stomi), dan gulame (Jonius trachycephalus). Ikan campuran tersebut walaupun jumlahnya sedikit, namun 
merupakan ikan yang khas terdapat di hilir sungai (Lampiran 2).

\section{Pendugaan Stok Ikan di Sekitar Tayan}

Pendugaan stok ikan di perairan sekitar Tayan dilakukan pada dua badan sungai, yaitu Sungai Kapuas dan anak sungainya (Sungai Tayan). Di Sungai Kapuas, pendugaan stok ikan dimulai dari perairan sekitar Pasar Tayan ke arah hulu, dan kisaran kedalaman air maksimalnya adalah 3 - $15 \mathrm{~m}$. Sedangkan di Sungai Tayan pengoperasian alat akustik mulai dari Pasar Tayan ke arah hulu sejauh sejauh 4,5 km, kisaran kedalaman air maksimalnya adalah 20 - 30 m (Lampiran 3, Gambar 2). Di Daerah Tayan (Kabupaten Sanggau), densitas stok di Sungai Kapuas adalah terendah (157 ind./Ha), jika dibandingkan dengan daerah lainnya. Hal ini kemungkinan disebabkan oleh habitat ikan yang sudah banyak rusak akibat banyaknya pemukiman dan tidak terdapatnya hutan rawa banjiran lagi. Di Sungai Tayan yang merupakan anak Sungai Kapuas, densitas stok ikannya lebih tinggi dari Sungai Kapuas (403 ind./Ha), kemungkinan karena anak sungai tersebut masih terdapat hutan rawa banjiran.

Berdasarkan pada data enumerator dan hasil pengambilan contoh, jenis ikan yang mendominansi di daerah Tayan yaitu baung (Mystus nemurus), bengalan (Puntius bulu), kelabau (Osteochilus melanopleura), kotol mulut (Amblyrhynchichthys truncatus), dan lais (Kryptopterus spp.). Jenis ikan tersebut sebagian besar adalah ikan herbivora dan omnivora, sedangkan jenis ikan karnivora yang berukuran besar seperti ikan gabus (Channa striata) dan belida berjumlah kurang dari 5\% (Lampiran 2).

\section{Pendugaan Stok Ikan di Kawasan Sentarum}

Pendugaan stok ikan di daerah kawasan Sentarum dilakukan pada badan Sungai Kapuas, anak Sungai Kapuas (Batang Tawang) dan Danau Belida (Lampiran 4, Gambar 3). Pendugaan stok pada badan Sungai Kapuas dilakukan mulai dari Semitau sampai Muara Batang Tawang berjarak 23,2 km, dan kedalaman maksimalnya berkisar 7,24-24,61 m. Tipe perairan tersebut merupakan perairan rawa banjiran yang kondisi ekosistemnya relatif baik dan stok ikan cukup tinggi (1.087 ind./Ha). Pendugaan stok ikan di Sungai Tawang (anak Sungai Kapuas) antara Muara Kapuas ke Empangau sejauh 15,5 km dengan kedalaman air maksimalnya berkisar $13-23 \mathrm{~m}$ menunjukkan bahwa adanya stok ikan yang cukup tinggi (1.548 ind./Ha). Pendugaan stok di Sungai Tawang antara Empangau dan Danau Belida sejauh
$37 \mathrm{~km}$, kedalaman air maksimalnya antara 3,5 - 29 $\mathrm{m}$ menunjukkan bahwa densitas stok ikan di perairan tersebut cukup tinggi, rata-rata 1.634 ind./Ha.

Stok ikan di kawasan Sentarum pada umumnya cukup tinggi, karena kawasan Sentarum merupakan daerah rawa banjiran yang banyak hutan rawa. Ekosistem seperti tersebut merupakan habitat yang produktif, karena banyak tersedia pakan alami (serangga air, perifiton, dan lain-lain), merupakan daerah pemijahan dan lindungan bagi anak-anak ikan. Di samping itu, hutan rawa juga merupakan sumber nutrien di perairan di mana daun-daun yang jatuh akan terurai menghasilkan nutrien.

Komposisi jenis ikan karnivora dengan herbivora adalah relatif seimbang. Jenis ikan herbivora yang mendominansi antara lain ikan senara (Ambassis wolffii), sepat (Trichogaster trichopterus), bauk (Labiobarbus spp.), palau (Osteochilus hasselti), dan biawan (Helostoma temminckii). Jenis ikan karnivora didominansi oleh antara lain langkung (Hampala macrolepidota), delak (Channa striata), tabirin (Belodontichthys dinema), dan toman (Channa micropeltes) (Lampiran 2).

Pendugaan stok ikan di badan air Sungai Kapuas mulai dari Muara Tawang sampai Djongkong sejauh $61,9 \mathrm{~km}$ dan kedalaman air maksimalnya berkisar 8,39 - 30 m diperoleh data stok ikan rata-rata 192,4 ind./Ha (Lampiran 5). Densitas stok ikan pada saat musim penghujan adalah jauh lebih kecil daripada musim kemarau, disebabkan karena pada saat musim penghujan, ikan menyebar ke segala penjuru perairan seiring dengan meningkatnya volume air daripada pada saat kemarau.

Pendugaan stok di wilayah Danau Empangau yang merupakan danau lindung mempunyai cakupan luasan sekitar 124 ha dengan kedalaman antara 1 - $21 \mathrm{~m}$. Saat musim penghujan, danau tersebut mempunyai densitas stok ikan cukup tinggi, rata rata 5.708 ind./ Ha (Lampiran 6; Gambar 4). Tingginya stok ikan di danau tersebut disebabkan karena perairan tersebut merupakan daerah yang dilindungi secara adat oleh masyarakat setempat sehingga kelestariannya relatif terjamin. Di samping itu, kondisi ekologi danau tersebut yang baik seperti terdapatnya hutan rawa (merupakan tempat pemijahan, tempat mencari pakan, dan perlindungan), relatif dalam sehingga tidak pernah mengalami kekeringan pada saat musim kemarau. Ikan yang mendominansi yaitu entukan (Thinnichthys thynnoides), bauk (Labiobarbus spp.), umpan (Puntioplites waandersii), baung, dan toman (Lampiran 2). 
Pendugaan Stok Ikan di Sungai Kapuas, Kalimantan Barat (Utomo, A.D.)

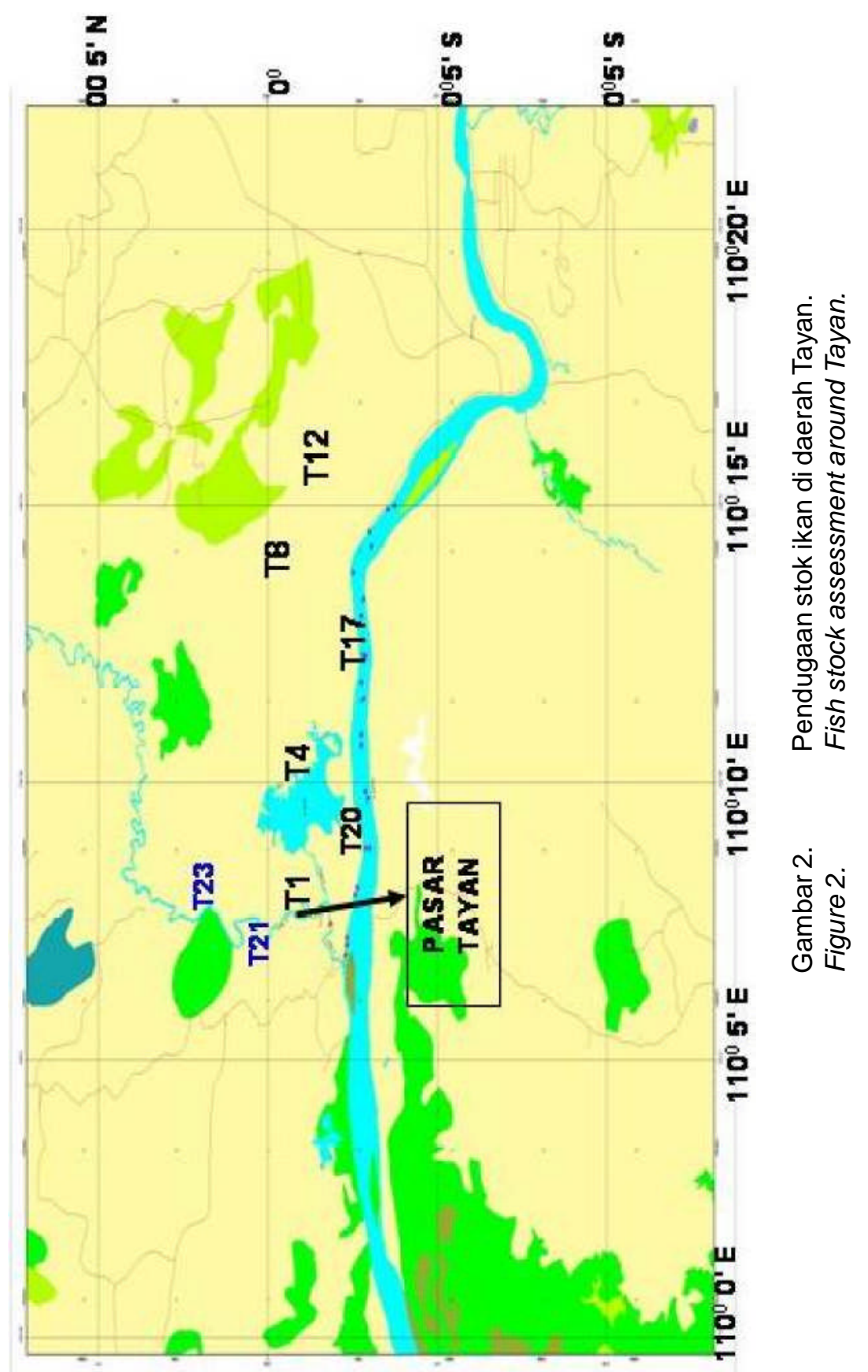




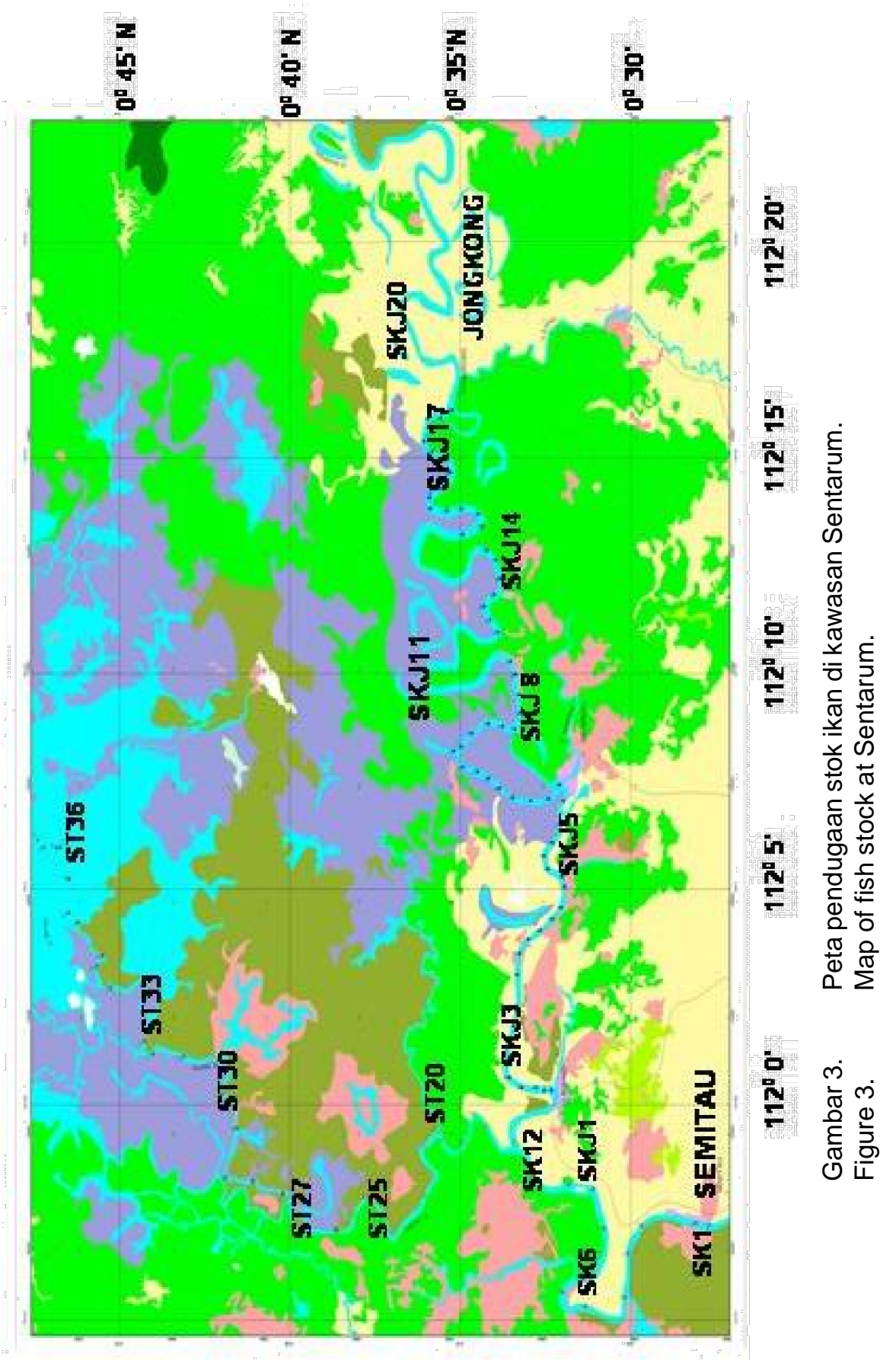


Pendugaan Stok Ikan di Sungai Kapuas, Kalimantan Barat (Utomo, A.D.)

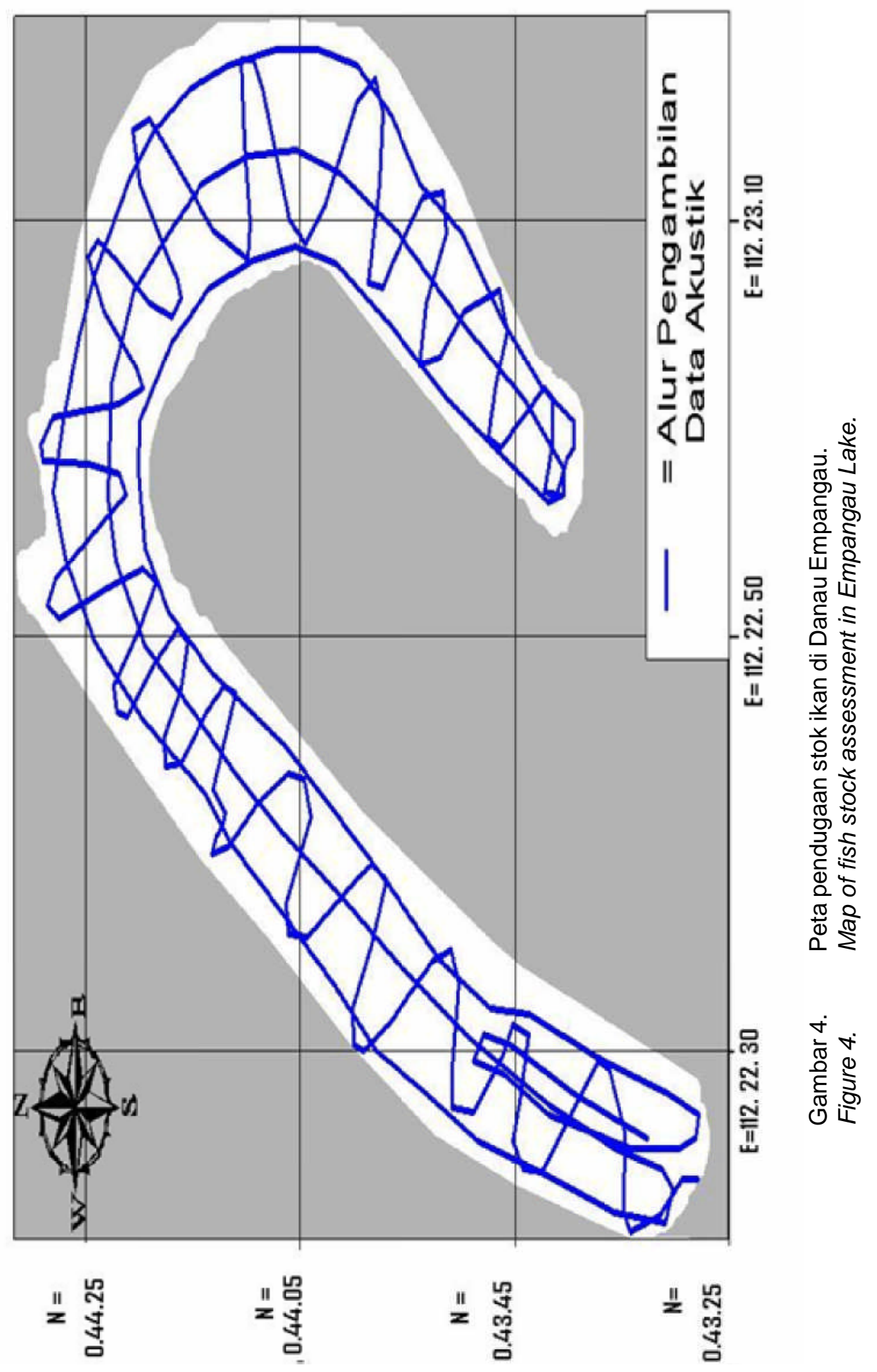




\section{KESIMPULAN DAN SARAN}

\section{Kesimpulan}

1. Densitas stok ikan di sepanjang aliran Sungai Kapuas sangat beragam antara 156 - 5.708 ind./ $\mathrm{Ha}$, tertinggi di Danau Empangau (5.708 ind. $/ \mathrm{Ha}$ ), karena merupakan danau lindung, kondisi perairan baik, banyak hutan rawa (tempat pemijahan, perlindungan, dan tempat mencari makanan), perairan dalam - tidak pernah mengalami kekeringan walaupun kemarau panjang. Selanjutnya, perairan bagian hilir sungai mempunyai stok ikan juga cukup tinggi (1.846 ind./ $\mathrm{Ha}$ ), hal ini disebabkan karena perairan di bagian hilir sungai adalah relatif subur, banyak nutrien dari hulu sungai menuju ke hilir.

2. Kawasan Sentarum mempunyai densitas stok cukup tinggi antara 1.548 - 1.634 ind./Ha, karena banyak terdapat hutan rawa yang merupakan habitat ikan. Pada saat musim penghujan, densitas stok ikan menurun, kawasan Sentarum hanya 197 ind./Ha, karena ikan menyebar ke segala penjuru perairan. Di daerah Tayan yang merupakan daerah pemukiman tidak banyak ditumbuhi hutan rawa dan perairannya dangkal, stok ikannya paling kecil walaupun pada saat musim kamarau, yaitu 157 ind./Ha di sungai utama dan 403 ind./Ha di anak sungainya.

\section{Saran}

Agar dilakukan pelestarian hutan rawa, pendalaman sungai yang dangkal, terutama pada lubuk sungai, karena tempat tersebut merupakan habitat yang baik bagi ikan yang berukuran besar.

\section{PERSANTUNAN}

Kegiatan dari hasil riset potensi dan tingkat pemanfaatan perikanan tangkap di Sungai Kapuas Kalimantan Barat, T. A. 2006, di Balai Riset Perikanan Perairan Umum Palembang, Mariana-Palembang.

\section{DAFTAR PUSTAKA}

Barnes, R. S. K. \& J. Green. 1971. The Estuarine Environment. Aplied Science Publisher Ltd. London.

Dudley, R. G. 1996. The fisheries of the Danau Sentarum wildlife reserve, West Kalimantan Indonesia. A. W. B. Bogor. Indonesia. 1-10.

Giesen, W. 1995. The flooded forest and black water lake of Sentarum, West Kalimantan. A. W. B. Bogor. 1-10.

Pollnac, R. B. \& S. P. Malvestuto. 1991. Biological and sosio economic condition for the development and management of riverine fishery resources on Musi and Kapuas River. Prosiding Temu Karya IImiah Pengelolaan Sungai dan Perairan Umum bagi Perikanan. Pusat Penelitian dan Pengembangan Perikanan. Jakarta. Prosiding Pusat Penelitian dan Pengembangan Perikanan/ No.22/1992. 67-80.

Sutikno. 1981. Status perikanan perairan umum Kalimantan Barat. Prosiding Seminar Perairan Umum. Pusat Penelitian dan Pengembangan Perikanan. Jakarta. 107-114.

Utomo, A. D. \& Asyari. 1999. Peran ekosistem hutan rawa air tawar bagi kelestarian sumber daya perikanan di Sungai Kapuas, Kalimantan Barat. Jurnal Penelitian Perikanan Indonesia. Vol. 3. 113.

Utomo, A. D., Z. Nasution, \& M. F. Sukadi. 1991. Potensi sumber daya perikanan daerah aliran Sungai Kapuas, Kalimantan Barat. Prosiding Temu Karya IImiah Pengelolaan Sungai dan Perairan Umum bagi Perikanan. Pusat Penelitian dan Pengembangan Perikanan. Jakarta. Prosiding Pusat Penelitian dan Pengembangan Perikanan/ No.22/1992. 67-80. 


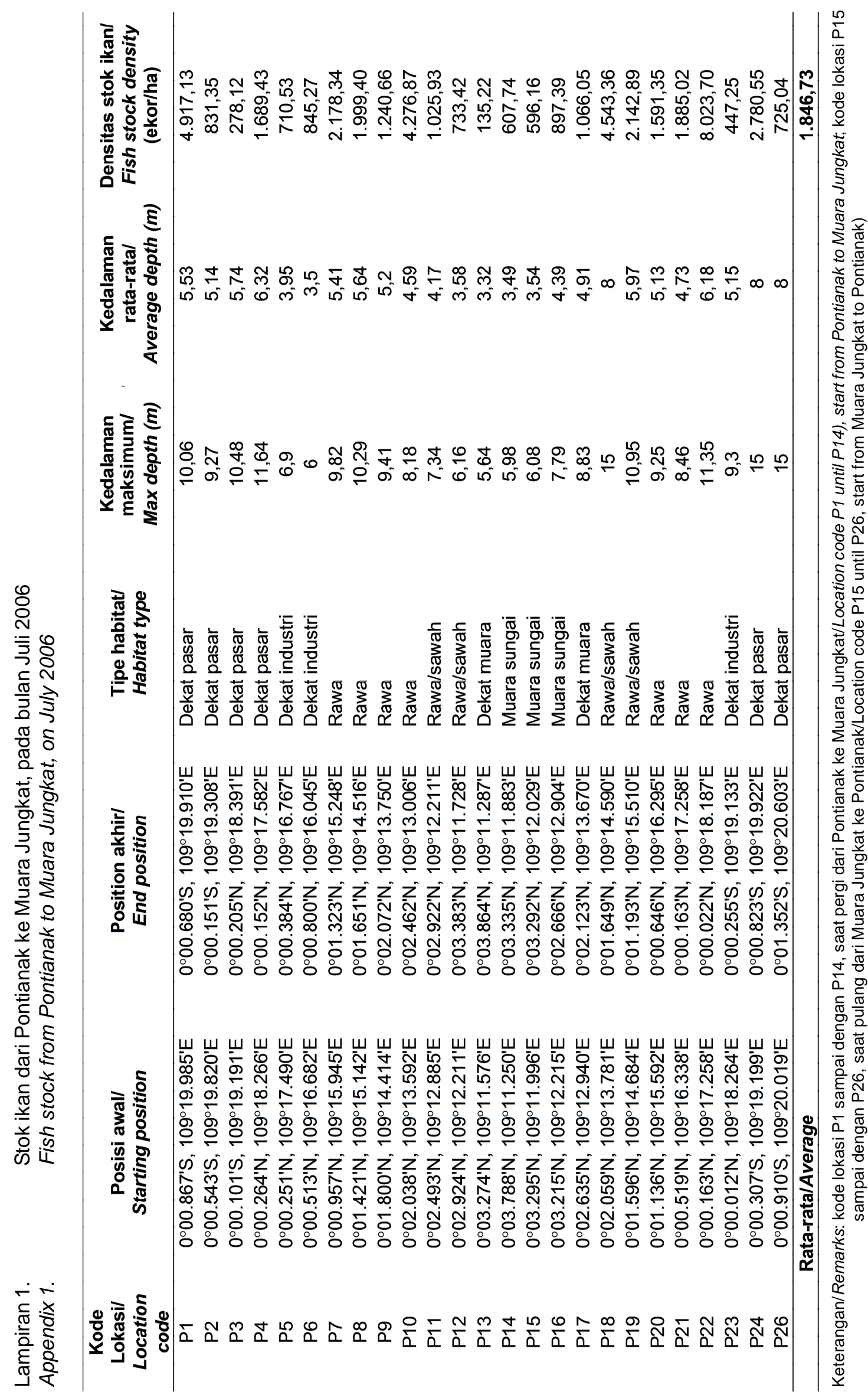


Lampiran 2. Komposisi jenis ikan pada tiap lokasi (\%)

Appendix 2. Fish composition in each location (\%)

\begin{tabular}{|c|c|c|c|c|}
\hline \multirow{2}{*}{ Jenis ikan/Species } & \multicolumn{4}{|c|}{ Lokasi/Location } \\
\hline & Hilir & Tayan & Sentarum & Empangau \\
\hline Adong (Hampala macrolepidota) & & 0,18 & 0,20 & 4 \\
\hline Anak ikan/campuran & 6 & & 4,89 & 7 \\
\hline Bangah (Pangasius huneralis) & & 0,08 & 0,20 & \\
\hline Bantak (Osteochilus microcephalus) & & & 0,40 & \\
\hline Bauk ketup (Labiobarbus vittatus) & & & 1,21 & 5 \\
\hline Bauk tadung (Labiobarbus ocellatus) & & & 0,60 & \\
\hline Baung (Mystus nemurus) & 12,45 & 11,06 & 1,61 & 5 \\
\hline Baung tikus (Bagrichthys macracanthus) & & 2,92 & & \\
\hline Belantau (Macrochirichthys macrochirus) & & 0,14 & 1,41 & \\
\hline Belida (Notopterus borneensis) & 9,60 & 0,01 & 1,01 & \\
\hline Bengalan (Puntioplites bulu) & 7,96 & 11,07 & 1,41 & 4 \\
\hline Betutu/Debuk (Oxyeleotris marmorata) & 0,67 & & 0,8 & \\
\hline Biawan (Helostoma temmincki) & & 2,91 & 1,81 & 4 \\
\hline Bis/Bilis (Clupeichthys bleekeri) & & 0,03 & 1,41 & \\
\hline Buntal (Tetraodon spp.) & & & 2,41 & \\
\hline Delak/Gabus (Channa striata) & & 0,14 & 1,81 & 3 \\
\hline Dilah/Lidah/Kenilah (Cynoglossus waandersii) & 0,27 & 0,07 & 1,81 & \\
\hline Duara (Pangasius polyuranodon) & 4,75 & 6,83 & 1,41 & \\
\hline Emperas (Cyclocheilichthys apagon) & & 3,09 & 0,80 & 4 \\
\hline Engkadi/kadik (Botia hymenophysa) & & & 1,21 & \\
\hline Engkuruyuk/Karuyuk (Ellapostoma megalomycter) & & & 0,40 & \\
\hline Entukan (Thynnichthys thynnoides) & & & 0,80 & 7 \\
\hline Gurami/Kalui (Osphronemus goramy) & 2,78 & & 1,21 & \\
\hline Jelawat (Leptobarbus hoeveni) & & & 1,81 & 4 \\
\hline Kakap (Lates calcalifer) & 2.44 & & & \\
\hline Kapas (Rohteicthys microlepis) & & & 2,62 & \\
\hline Kelabau (Osteochilus melanopleura) & 4,75 & 10,87 & 1,81 & 2 \\
\hline Kebali (Osteochilus schlegelii) & & & 0,20 & 4 \\
\hline Kedukul (Amblyrhynchichthys truncatus) & & & 1,81 & \\
\hline Kelampa (Parachela oxygasteroides) & & & 1,41 & \\
\hline Kelik/Lele (Clarias sp.) & & 0,05 & 1,61 & \\
\hline Kenyulung (Xenontodon canciloides) & & & 1,41 & \\
\hline Kenyuwar (Luciosoma trinema) & & & 0,20 & \\
\hline Kerandang (Channa sp.) & & 0,19 & 1,81 & \\
\hline Kotol mulut (Amblyrhynchichthys truncatus) & & 9,52 & & \\
\hline Kujam (Labiobarbus festivus) & & 4,54 & 0,60 & \\
\hline Kukum (Barbichthys laevis) & & 2,76 & 0,20 & 4 \\
\hline Kurau (Polystonemus multifilis) & 3,48 & & & \\
\hline Kusang/Kujam (Labiobarbus festivus) & & & 0,20 & \\
\hline Lais (Kryptopterus spp.) & 6 & 9,64 & 2,01 & 3,5 \\
\hline Lais junggang (Kryptopterus apogon) & & & 1,41 & \\
\hline Lais sengarat (Kryptopterus sp.) & 20,8 & & 0,80 & \\
\hline Landin (Mystus negricep) & & & 1,41 & \\
\hline Langkung (Hampala macrolepidota) & & & 2,01 & \\
\hline Mentulu/Pengulu(Barbichthys laevis) & & 0,84 & 0,6 & \\
\hline Miadin (Osteochilus intermedius) & & & 0,80 & \\
\hline Nuayang (Pseudeutropius sp.) & & & 1,41 & \\
\hline Pacol (Hypopthalmichthys sp.) & 2 & 0,03 & 0,2 & \\
\hline Palau (Osteochilus hasselti) & & 13,38 & 2,01 & 4 \\
\hline Pati (Mystus sp.) & & & 2,01 & 3 \\
\hline Pati terung/Patik layar (Bagrichthys hypselopterus) & & & 0,20 & \\
\hline
\end{tabular}


Lanjutan Lampiran 2.

Continuing Appendix 2.

\begin{tabular}{|c|c|c|c|c|}
\hline \multirow{2}{*}{ Jenis ikan/Species } & \multicolumn{4}{|c|}{ Lokasi/Location } \\
\hline & Hilir & Tayan & Sentarum & Empangau \\
\hline Patong muntuk (Nandus nebolusus) & & & 0,20 & \\
\hline Patong rimba (Nandus nebolusus) & & & 0,20 & \\
\hline Patung (Pristolepis fasciatus) & & 1,36 & 1,81 & 3 \\
\hline Pengkah/Senara (Ambassis wolffii) & & 3,09 & & \\
\hline Penyulung (Xenentodon sp.) & & & 0,20 & \\
\hline Piyam (Leptobarbus melanopterus) & & & 0,20 & \\
\hline Pian (Channa marulioides) & & 0,38 & 1,01 & 3 \\
\hline Pisang (Bagrichthys macracanthus) & & & 3,22 & \\
\hline Rebas (Cyclocheilichthys sp.) & & & 0,20 & \\
\hline Rik (Mystus micrachantus) & & & 1,21 & \\
\hline Ringau (Datniodes sp.) & & 1,35 & 2,01 & \\
\hline Runtu (Channa lucius) & & & 1,81 & 2 \\
\hline Samah (Tor spp.) & & & 0,20 & \\
\hline Seladang/Patin (Pangasius nasutus) & 4,18 & 0,71 & 0,2 & 2 \\
\hline Seluang (Rasbora spp.) & & & 2,21 & \\
\hline Seluang buluh (Rasbora boneensis) & & & 0,60 & \\
\hline Seluang maram (Pectenocypris balaena) & & & 0,20 & \\
\hline Seluang minyak (Rasbora trilineata) & & & 0,20 & \\
\hline Senara (Ambassis wolffii) & & & 2,21 & \\
\hline Sepat (Trichogaster trichopterus) & & & 2,41 & \\
\hline Sialuri (Setepina melanochir) & & & 0,40 & \\
\hline Silu kerisik/Hijau (Sclerophages formusus) & & & 0,20 & \\
\hline Sumpit (Toxotes chatareus) & & 0,03 & 1,61 & \\
\hline Suwadi/Suain (Barbodes gonionotus) & & & 0,20 & \\
\hline Tabirin (Belodontichthys dinema) & & & 1,21 & 1,5 \\
\hline Tamudau (Epalzeahynchus sp.) & & & 0,80 & \\
\hline Tamunit (Labeo chrysophekadion) & & & 2,21 & 4 \\
\hline Tapa (Wallago leerii) & 6,86 & 1,37 & 2,82 & 2 \\
\hline $\begin{array}{l}\text { Temirang/Sembilang } \\
\text { (Plotosus lineatus/Paraplotosus albilabris) }\end{array}$ & 1,33 & & & \\
\hline Tengadak (Barbodes schwanefeldii) & 1,27 & 1 & 0,80 & 3 \\
\hline Tilan (Mastacembelus spp.) & & 0,08 & 2,21 & \\
\hline Toman (Channa micropeltes) & 2,41 & & 2,41 & 5 \\
\hline Udang (Macrobrachium rosenbergii) & & 0,12 & 0,20 & \\
\hline Ulan uli (Botia macrachanta) & & 0,16 & 1,21 & \\
\hline Umpan (Puntioplites waandersii) & & 0 & 2,62 & 7 \\
\hline Lain-lain & & & 0,40 & \\
\hline Total & 100 & 100 & 100 & 100 \\
\hline
\end{tabular}




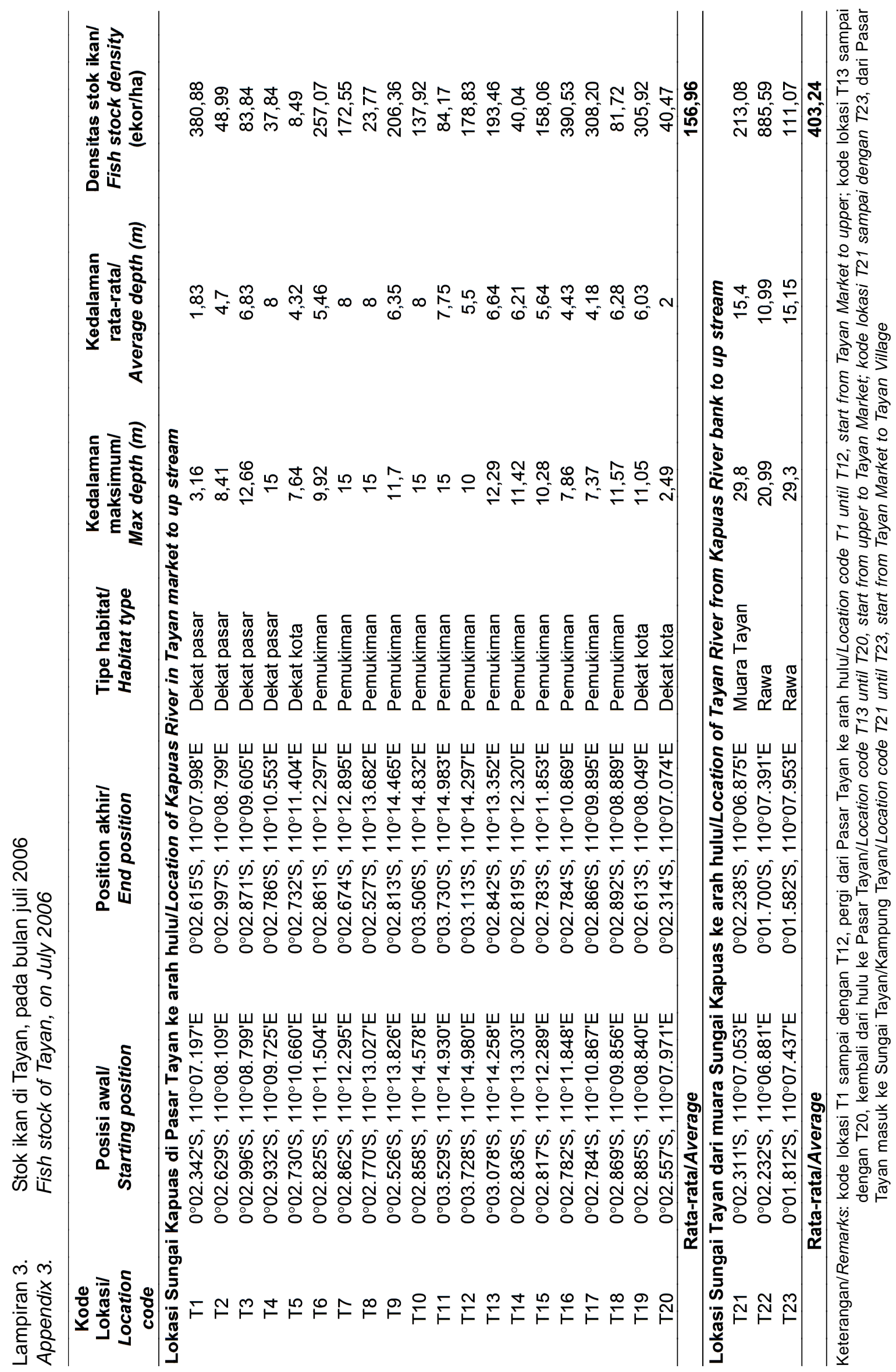




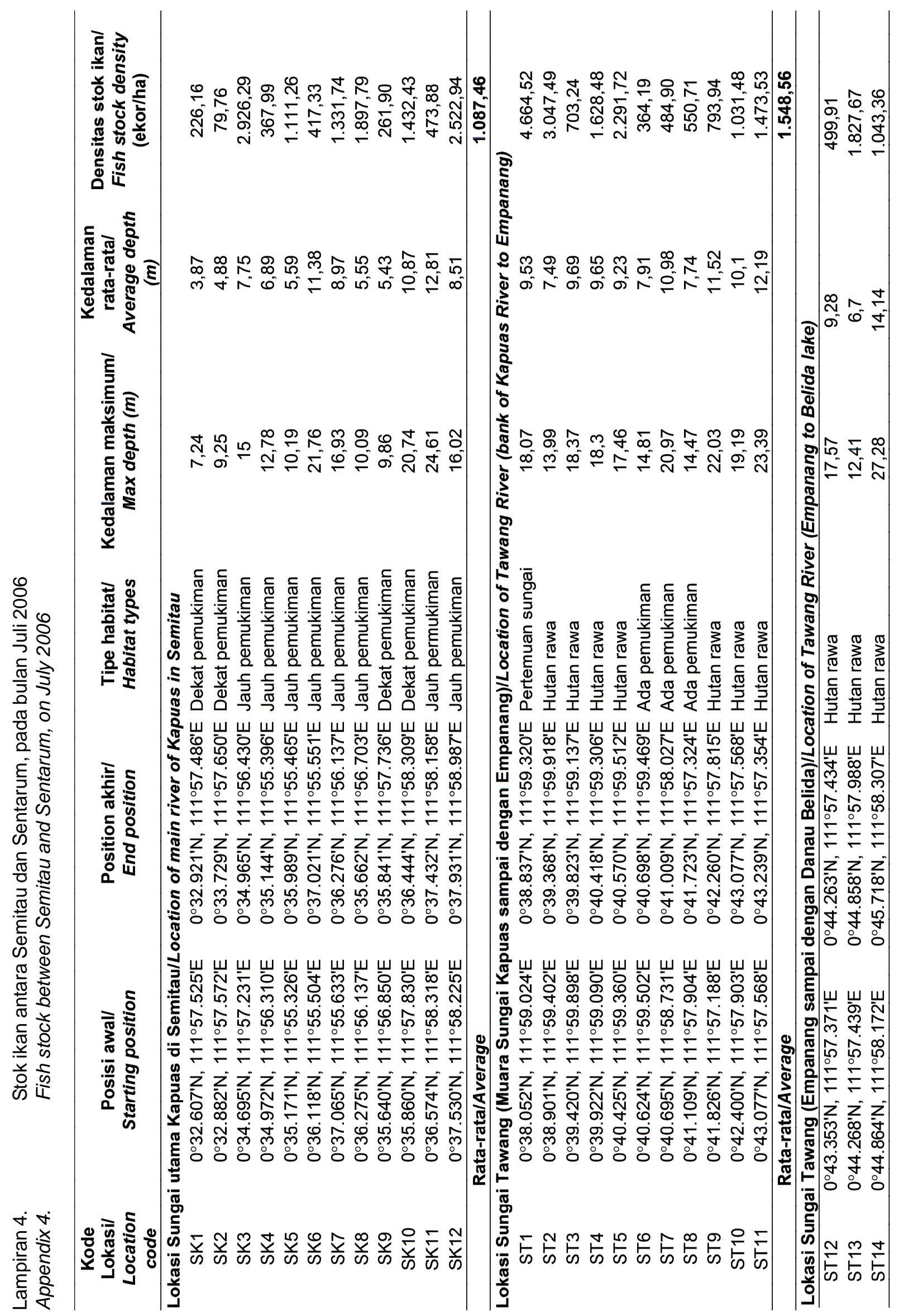




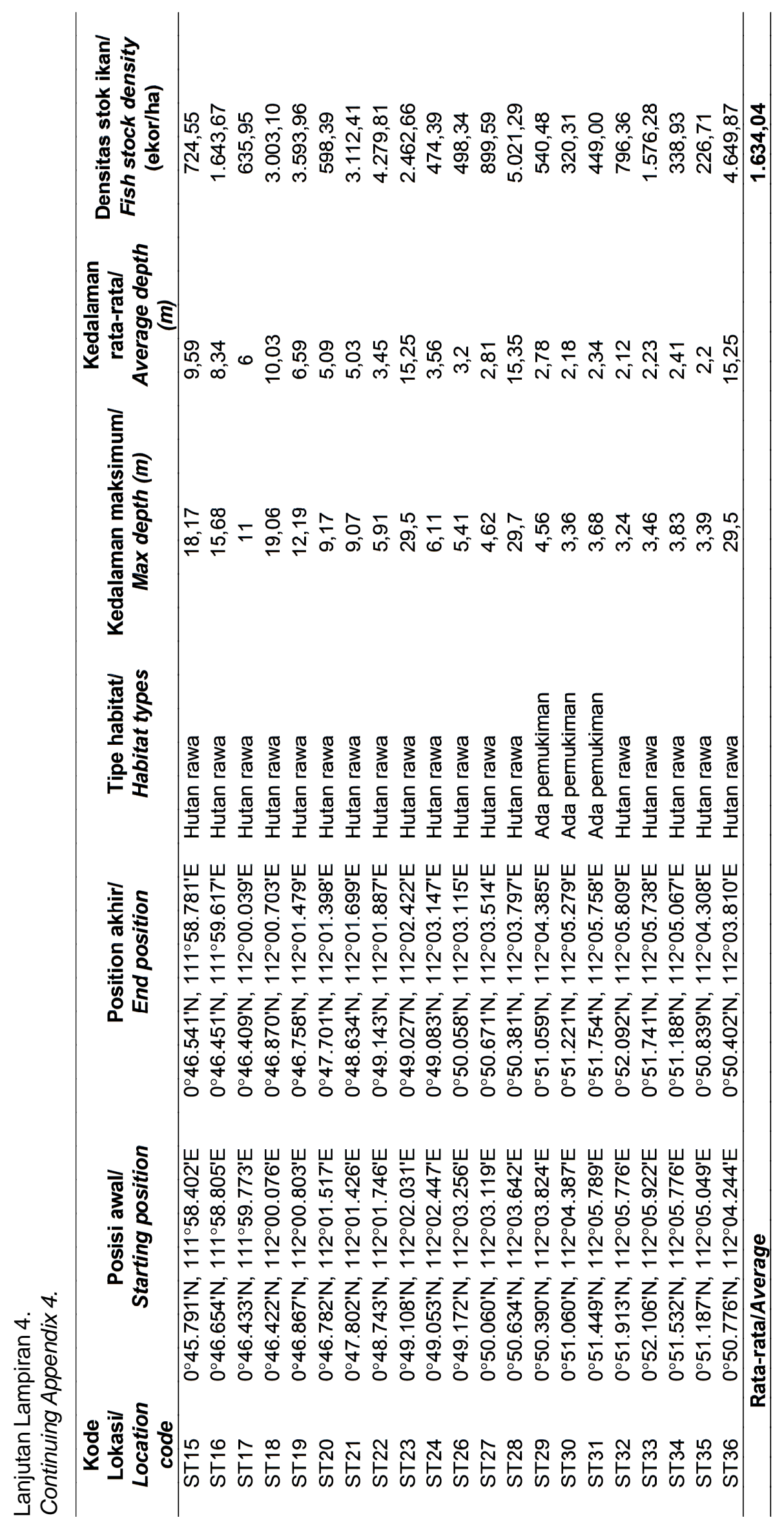




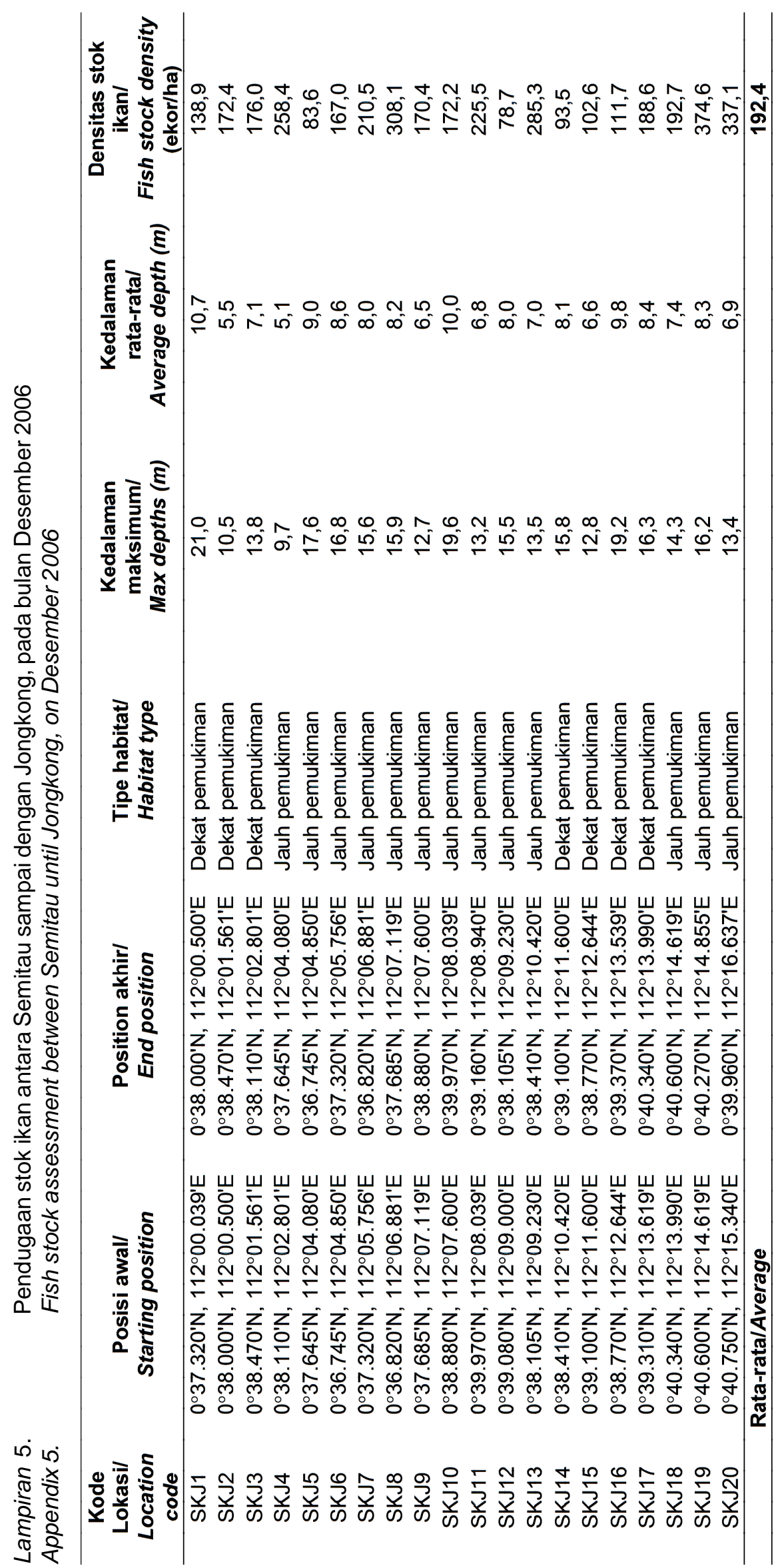




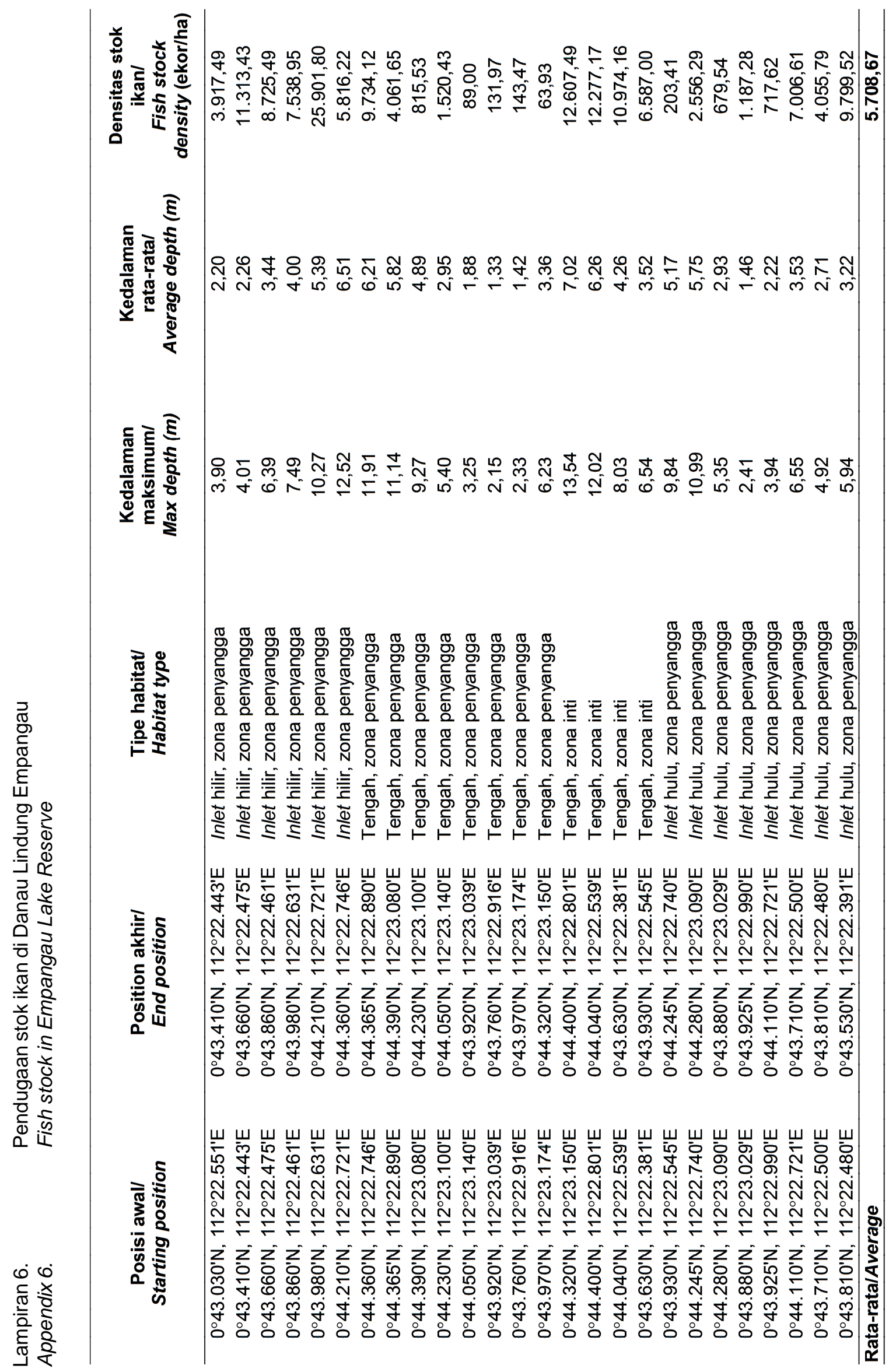

